\title{
Effect Of Role Play Method On Food Choice Behavior In State Basic Students 060933 District Medan Johor City Medan Year 2016
}

\author{
Rika Khairunnisya Sa'bani ${ }^{1}$, Etti Sudaryati ${ }^{2}$, Ernawati Nasution ${ }^{3}$ \\ ${ }^{I}$ Postgraduate Student Public Health Science University of North Sumatera, Medan, Sumatera Utara 20222, \\ Indonesia \\ ${ }^{23}$ University of North Sumatera, Jl. Abdul Hakim, Medan, Sumatera Utara 20222, Indonesia
}

\begin{abstract}
Selection of snack food is one of health behaviors that are going to be a grave concern because of lack of safety level. The habit of eating snack food is very popular among students. Nutrition education with the role play method aims to make students change their behavior to be better, including in choosing snack foods. The purpose of this research was to investigate the influence of role-play method to the selection behavior of snack food of 060933 public elementary school students at Medan Johor district in Medan year of 2016.The research was a quasi-experiment with a pretest-posttest design with an intervention. The experiment group was 060933 elementary school, and the control group was 067690 elementary school students. Samples in this study were 36 students who received three times of intervention. Measurement of students' knowledge, attitude and behavior were done twice: before and after the intervention. Data was analyzed by using test independent sample T-testand the results of the research showed that there was the influence of role play method on the selection of snack food on students' knowledge $(p=0.000)$, attitude $(p=0.000)$ and action $(p=0.010)$ of 060933 public elementary school students in Medan. The conclusion of this study is role play influence improving knowledge, attitude, and action of students on choosing of snack food. Suggested to 060933 Elementary School and 067690 Elementary School to guide, direct and remain the students to keep choosing safe and healthy snack food, such as make posters. Suggested to Medan Johor Primary Health Care and BPOM Medan to supervise of snack food around the school actively and regularly, especially in 060933 Elementary School and 067690 Elementary School.
\end{abstract}

Keyword:- Role Play Method, Elementary Students' Knowledge, Attitude and Action, Snack Food

\section{INTRODUCTION}

One of the food priorities of serious concern is the snack food of school children. The low level of food security of students snacks is still an important issue (BPOM, 2011). In 2014 there is a decrease in the percentage of student snacks eligible, which is equal to $76.18 \%$ where the target is $90 \%$ (Ministry of Health, 2015).The Government through various programs of food and nutrition intervention in the community strives to improve nutrition in Indonesia. One type of intervention that can be done by the government is through nutrition education. Nutrition education is an effort to make a person or a group of individuals aware of the importance of nutrition. Efforts to socialize and deliver nutritional messages as part of nutritional education become an essential element to improve people's nutritional status (Ikada, 2010). One strategy for gaining behavioral change is by providing information to increase knowledge so that it raises awareness and ultimately people will behave by that knowledge (Aprillia, 2013). Nutrition education should start from an early age (Ikada, 2010). School-based nutrition education is an effective and efficient education effort to reach the large population segment of schoolchildren (Hermina, 2010). Nutrition education is always meant for students to change the behavior of food consumption to better behavior. (Ikada, 2010).

Factors that influence the formation of behavior could be split into two, namely internal and external factors. Internal factors include knowledge, intelligence, perception, emotion, motivation, and so on which works to cultivate external stimuli, while external factors include the environment, both physical and nonphysical such as climate, social, socioeconomic, cultural, and so forth (Aprillia, 2013 ).

School-aged children tend to be active, playful, and ask many questions so that the chosen method allows the child to play a full role in learning so that children value the knowledge and skills gained from their efforts. Various methods that encourage participation and involvement of children in learning activities include games, group discussions, demonstrations (Sartika, 2012). Therefore, the most appropriate concept of education in this period is the idea of teaching combined with playing (Ikada, 2010). One means of education under the notion of fun is through role play (role play). 
Role play is the method of learning as part of the simulation are planned to create historical events, actual events or future events. By applying the role-playing procedure in learning, the children can easily absorb messages or materials, besides the children learn to work together, tolerance and understand the feelings of his friends (Zumaroh, 2012). Role play method is suitable for a small group with the target of fewer than 15 people (Notoadmojo, 2007). Role play methods will increase student interest and achievement (Peni, 2009) and will improve student learning outcomes Haryanto (2014).

Based on research conducted by Wulandari (2007) obtain results in a score of nutritional knowledge among school children who received nutritional education with the role-playing method to increase significantly. Also, research conducted by Hidayati (2011) suggests that there is the influence of nutrition training with role play and audiovisual methods on the level of knowledge about nutrition in Puskesmas Kasihan I Bantul.

Elementary School 060933 is one of 56 public and private elementary schools located in Medan Johor District. The school has one canteen shared with other elementary schools in the school complex. The cafeteria is inadequate, and many food vendors sell outside the school complex by the sale of a variety of foods and drinks. This snack seller never recorded the amount and type of food and beverages sold. Students are allowed to buy snack foods contained in the cafeteria and outside the school. School education efforts to students on the selection of food snacks only in the form of discourse during the ceremony, no special educational efforts. Also, there is no participation of puskesmas or BPOM in education and in assessing the safety of snack foods that exist in the school environment. The knowledge of some of the students interviewed indicates that the level of students' knowledge is still low regarding both healthy and unhealthy snack foods. Preliminary research on food and beverages sold in the school environment shows that the low level of snack food security in the school environment, which can cause health problems to students.

\section{RESEARCH METHODOLOGY}

This research is quasi-experimental research (quasi-experiment) with pretest-posttest control group design with one kind of treatment. Before starting treatment, both groups were given the initial test or pretest to measure the initial conditions (O 1). Subsequently in the experimental group treated $(X)$ and in the control group was not given. After completion of treatment, both groups were given the test again as posttest (O 2) (Arikunto, 2000).

Provision of intervention in the experimental group was handled for 21 days. The experimental group will receive intervention by the method of role play three times in 3 weeks in the school. The sample of this research is split into two groups namely, the experimental group and the control group. The experimental group is the Grade V student of SD Negeri 060933 which is 36 students. The control group is the students of grade V of SD Negeri 067690 which is 72 students. Both schools have the same characteristics of having only one (1) less cafeteria, there are many street food vendors outside the school gates and have not been given any food about snack food and do not have adequate School Health Care (UKS). Characteristics of students are also the same, covering the middle-low socioeconomic conditions, rarely bring supplies to school and often snacks in the canteen or food vendors outside the school gate. This study includes the preparation phase of this research is to collected preliminary survey data and determine the characteristics of the survey area and to identify survey respondents and stages of implementation in the form of a pre-test, intervention by the method of role play and posttest. Data on knowledge, attitudes, and actions taken before and after the treatment collected by questionnaire. Besides, to strengthen the pretest and posttest assessment the results were observed in the student action choose street food using a checklist sheet. Analyses-independent test conducted weeks to determine differences in knowledge, attitudes, and actions of students on the selection of snack food before and after treatment

\section{RESULT AND DISCUSSION}

Respondents in this study were students of class V (five) in primary schools 060933 Medan as an experimental group that received intervention by the method of role play in improving the behavior of choosing snack food was excellent and the students of class V (five) SDN 067690 Terrain as a control group Did not get any research intervention. Distribution of respondent characteristics of experimental groups and control groups by sex can be seen in the table in Table 1 below:

Table 1. Distribution of Respondent's Characteristics of Experiment Group and Control Group by Sex

\begin{tabular}{lcccc}
\hline \multirow{2}{*}{$\begin{array}{c}\text { Jenis } \\
\text { Kelamin }\end{array}$} & \multicolumn{3}{c}{ Jumlah } \\
\cline { 2 - 5 } & SDN 060933 & \% & SDN 067690 & \% \\
\hline Laki-laki & 19 & 52,3 & 38 & 52,3 \\
Perempuan & 17 & 47,2 & 34 & 47,2 \\
\hline Jumlah & $\mathbf{3 6}$ & 100,0 & $\mathbf{7 2}$ & 100,0 \\
\hline
\end{tabular}


Distribution of respondent characteristic of experimental group and control group by age can be seen in Table 2 below:

Table 2. Distribution of Respondent Characteristics of Experiment Group and Control Group by Age

\begin{tabular}{c|cccc}
\hline Usia (Tahun) & \multicolumn{4}{|c}{ Jumlah } \\
\cline { 2 - 5 } & SDN 060933 & \% & SDN 067690 & $\%$ \\
\hline 9 & 1 & 2,8 & 0 & 0,0 \\
10 & 10 & 27,8 & 27 & 37,5 \\
11 & 21 & 58,3 & 37 & 51,4 \\
12 & 4 & 11,1 & 8 & 11,1 \\
\hline Jumlah & $\mathbf{3 6}$ & 100,0 & $\mathbf{7 2}$ & 100,0 \\
\hline
\end{tabular}

Based on the pre-test and post-test scores of students' knowledge can be seen before and after nutrition education about the selection of street food by the method of role play. In this study, knowledge is divided into three categories, i.e., real knowledge ( $>75 \%$ correct answer), enough (50-75\% correct answer) and less $(<50 \%$ correct answer). When viewed from the replies to the pre-test and post-test students' knowledge on their increase in average scores between pre-test and post-test in the experimental group and the control group but the growth in the control group by the treatment group, the result can seein Table 3:

Table 3. Distribution of Respondents Based on Knowledge of Selection of Food Snack

\begin{tabular}{|c|c|c|c|c|c|c|c|c|c|}
\hline \multirow{3}{*}{ No } & \multirow{3}{*}{ Pengetahuan } & \multicolumn{4}{|c|}{ Kelompok Eksperimen } & \multicolumn{4}{|c|}{ Kelompok Kontrol } \\
\hline & & \multicolumn{2}{|c|}{ Pre-Test } & \multicolumn{2}{|c|}{ Post-Test } & \multicolumn{2}{|c|}{ Pre-Test } & \multicolumn{2}{|c|}{ Post-Test } \\
\hline & & $\mathbf{n}$ & $\%$ & $\mathbf{n}$ & $\%$ & n & $\%$ & $\mathrm{n}$ & $\%$ \\
\hline 1 & Baik & 25 & 69,4 & 36 & 100,0 & 45 & 37,5 & 52 & 72,2 \\
\hline 2 & Sedang & 11 & 30,6 & 0 & 0,0 & 27 & 62,5 & 20 & 27,8 \\
\hline & Jumlah & 36 & 100,0 & 36 & 100,0 & 72 & 100,0 & 72 & 100,0 \\
\hline
\end{tabular}

Increasing the score of knowledge in the experimental group after obtaining the intervention shows that the students have obtained relevant information about the selection of healthy snack foods. The information is still remembered by the students well, and this can happen due to the provision of information by the method of role play given more than once, that is three (3) times. Provision of a group who performed the role play method implemented three (3) times at intervals of 7 days, so it is thought that students still remember the content of the message in playing a role. This is consistent with the concept of sleeper effect put forward by Brigham that people still remember the comfortable of the message delivered within 10-14 days after the message was displayed (Anwar, 2005).

The results of the analysis of Independent Sample T-test in the treatment group and the control group obtained a probability value $(\mathrm{p}=0.000)$ were $(\mathrm{p}<0.05)$. From the results of the analysis can be concluded that on average there is a real difference between the students' knowledge of the treatment group and the control group. This suggests that the increased awareness of the respondent to do with the provision of information by using role play. The use of role play method in this study makes students gain knowledge in a fun way, i.e., while playing a role.

At the time of role play, the students seemed eager and enthusiastic in playing their respective roles. Role play is a fun learning method for role play involving elements of the game and provides flexibility to students to be active. It is by the characteristics of elementary students that the outstanding characteristics of elementary school children are to play, to move, to work in groups and to feel or do/demonstrate things directly. A fun learning method can increase students' interest in learning. Interactive learning will produce a learning climate that supports and motivates students to participate actively and creatively in learning so that it is expected to improve the thinking and understanding of students to achieve the desired learning objectives which one of them could be seen from the acquisition of student learning outcomes (Kisnawaty P, 2013).

The attitude of the respondents in the experimental group on the selection of street food were judged according to the pre-test and post-test before and after the intervention is given in the form of role play method. Assessment of respondent attitude is divided into 3 (three) categories i.e., good (> 75\% correct answer), enough $(50-75 \%$ correct answer) and less $(<50 \%$ correct answer).The results showed that the average score of the attitude of pre-test or before the selection of nutritional education on street food by the method of role play in the respondents are given the experimental group before the intervention was 35.44 and after the role-play method to increase. This can be seen in Table 4: 
Table 4. Distribution of Respondents' Attitudes about the Selection of Snack Food

\begin{tabular}{|c|c|c|c|c|c|c|c|c|c|}
\hline \multirow{3}{*}{ No } & \multirow{3}{*}{ Sikap } & \multicolumn{4}{|c|}{ Kelompok Eksperimen } & \multicolumn{4}{|c|}{ Kelompok Kontrol } \\
\hline & & \multicolumn{2}{|c|}{ Pre-Test } & \multicolumn{2}{|c|}{ Post-Test } & \multicolumn{2}{|c|}{ Pre-Test } & \multicolumn{2}{|c|}{ Post-Test } \\
\hline & & $\mathbf{n}$ & $\%$ & $\mathbf{n}$ & $\%$ & $\mathbf{n}$ & $\%$ & $\mathbf{n}$ & $\%$ \\
\hline 1 & Baik & 5 & 13,9 & 20 & 55,6 & 14 & 19,4 & 21 & 29,2 \\
\hline 2 & Sedang & 23 & 63,9 & 13 & 36,1 & 52 & 72,2 & 48 & 66,7 \\
\hline 3 & Kurang & 8 & 22,2 & 3 & 8,3 & 6 & 8,3 & 3 & 4,2 \\
\hline & Jumlah & 36 & 100,0 & 36 & 100,0 & 72 & 100,0 & 72 & 100,0 \\
\hline
\end{tabular}

The increased attitude in both categories due to the stimulus in the form of nutrition education conducted by the method of role play. This may indicate a positive influence of role play method in the attitudes of students in choosing a snack in the experimental group and is directly proportional to the increase of students' knowledge.

The results of the analysis of Independent Sample T-test is obtained the probability value $(p=0.000)$ where ( $\mathrm{p}<0.05$ ), indicating that there is a positive influence in the form of the difference between the students' attitudes before and after intervention by the method of role play about the selection of street food in the attitudes of students. An increase in knowledge and attitudes of students in choosing a snack food caused by the provision of information by the method of role play. Improved attitudes about the selection of street food can be called due to the delivery of health information with role-play method because this approach causes the delivery of information in an interesting and demanding interest and participation of students so that students do not get bored during the activity.

Measures of respondents in the experimental group on the selection of street food were evaluated according to the pre-test and post-test before and after the intervention is given in the form of role play method. Assessment of respondent action is divided into 3 (three) categories i.e., good (> 75\% correct answer), enough (50-75\% correct answer) and less ( $<50 \%$ correct answer). In general, respondents' actions before and after the treatment group nutrition education conducted by the method of role play increased in both categories. This can be seen in Table 5 below:

Table 5. Distribution of Respondents' Action on the Selection of Snack Food

\begin{tabular}{|c|c|c|c|c|c|c|c|c|c|}
\hline \multirow{3}{*}{ No } & \multirow{3}{*}{ Tindakan } & \multicolumn{4}{|c|}{ Kelompok Eksperimen } & \multicolumn{4}{|c|}{ Kelompok Kontrol } \\
\hline & & \multicolumn{2}{|c|}{ Pre-Test } & \multicolumn{2}{|c|}{ Post-Test } & \multicolumn{2}{|c|}{ Pre-Test } & \multicolumn{2}{|c|}{ Post-Test } \\
\hline & & $\mathbf{n}$ & $\%$ & $\mathbf{n}$ & $\%$ & $\mathbf{n}$ & $\%$ & n & $\%$ \\
\hline 1 & Baik & 23 & 63,9 & 29 & 80,6 & 39 & 54,2 & 52 & 72,2 \\
\hline 2 & Cukup & 13 & 36,1 & 7 & 19,4 & 28 & 38,9 & 48 & 23,6 \\
\hline 3 & Kurang & 0 & 0,0 & 0 & 0,0 & 5 & 6,9 & 3 & 4,2 \\
\hline & Jumlah & 36 & 100,0 & 36 & 100,0 & 72 & 100,0 & 72 & 100,0 \\
\hline
\end{tabular}

The results of the analysis of Independent Sample T-test treatment group and the control group is known probability value $(\mathrm{p}=0.010)$ were $(\mathrm{p}<0.05)$, indicating that there is an influence on the selection of roleplay method of street food in the actions of the students before and after getting intervention. This is not in line with research conducted by Dilliani in 2011 on the Influence of Health Education with Role Play against Method Personal Hygiene Behaviors in Children Class III SD Pandak I Bantul. Dilliani (2011) suggests that there is no difference in the behavior of third-grade student's personal hygiene Bantul Pandak first experimental group and the control group after health education with the role play method. This may be caused by some respondents as many as 16 people and intervene with methods of role play is only done as much as 1 (one). Role play method is suitable for a small group with a target of fewer than 15 people (Notoadmojo, 2007). Playing a role with a large group has many obstacles and constraints in communication that will interfere with the effectiveness of communication. This is also by Maltz's research in Sudarmin (2014) that it takes a minimum of 21 consecutive days to form daily habits carried from small to adult. Core (2003) also mentions that practicing new behaviors for approximately 21 days will become a habit.

Based on observations, most students of SD Negeri 060933 Medan buy food snacks at school, both in the canteen and food vendors outside the school gate. This is comparable to Kristianto Y's (2013) research on the determinants of the choice of snack foods for elementary school students which revealed that almost all students buy school snacks every day. This indicates the need to increase students' understanding of the choice of healthy snack foods. Observations on the action of elementary students 060933 Medan in choosing food snacks can be seen in Table 6: 
Table 6. Observation Results on Respondent Action in the Selection of Food Snack

\begin{tabular}{llrr}
\hline No & Faktor yang Dinilai & \multicolumn{2}{c}{ Tindakan } \\
\cline { 3 - 4 } & & $\mathbf{n}$ & \multicolumn{1}{c}{$\%$} \\
\hline 1 & Membeli aneka gorengan & 5 & 13,9 \\
2 & Makanan atau minuman dicurigai dengan & 5 & 13,9 \\
& pemanis buatan & & \\
3 & Makanan dicurigai dengan pewarna buatan & 5 & 13,9 \\
4 & Makanan dicurigai berpengawet & 5 & 13,9 \\
5 & Makanan dengan tekstur yang tidak baik & 3 & 11,1 \\
6 & Makanan yang terpapar debu & 4 & 22,2 \\
7 & Membaca tanggal kadaluarsa pada makanan & 8 & 8,3 \\
\hline & kemasan & & 3 \\
\hline
\end{tabular}

The result of observation of the action of the students of SD Negeri 060933 Medan in choosing a snack food showed an increase in the number of students reading the expiration date on food packaging. Regarding "food safety" is not just a food packaging but also as a protective wrap so that the food is safe to eat. Food packaging also has health functions, preservation, ease, uniformity, promotion, and information (Suswanti $\mathrm{K}$, 2013). This is in proportion to the results of increased knowledge, attitudes and actions of students in reading expiration dates on food packaging. Kristianto Y (2013) research about the determinant factor of the selection of snack food on elementary school students suggests that there is a significant relationship between the knowledge of nutrition and snack food with the habits of food consumption of snack. This is also under research Fitri CN (2012) that nutritional knowledge is a crucial factor in determining the attitudes and habits of a person to the food. Nutrition knowledge is an essential prerequisite for the occurrence of changes in attitude and nutritional behavior, and knowledge is also one of the considerations of a person in choosing and consuming food. The better one's nutritional knowledge will pay attention to the quality and quantity of food consumed. (Suswanti K, 2013).

\section{CONCLUSION}

Based on the results of research and discussion, we conclude that there are differences in knowledge, attitudes, and actions 060933 Terrain Elementary School students in choosing a snack at the time before and after the intervention by the method of role play, there are few suggestions that could do, such asFor SD Negeri 060933 and SD Negeri 067690 Medan is expected to provide guidance, direction and remind students always to eat good food and healthy snacks, one of them by making health promotion media such as posters.

1. For Puskesmas Medan Johor and BPOM Medan City to actively and regularly supervise of snack food that exists in the school environment, especially at SD Negeri 060933 Medan and SD Negeri 067690 Medan.

\section{REFERENCES}

[1] Aprilia, B.A., 2011. Faktor yang Berhubungan dengan Pemilihan Makanan Jajanan pada Anak Sekolah Dasar. Artikel Penelitian, FK UNDIP.

[2] Arikunto, S., 2000. Prosedur Penelitian: Suatu Pendekatan Praktek, Jakarta : Rineka Cipta.

[3] Azwar, S., 2005. Sikap Manusia Teori dan Pengukurannya. Yogyakarta: Pustaka Pelajar.

[4] BPOM, 2011. Pentingnya Promosi Keamanan Pangan di Sekolah Untuk Menyelamatkan Generasi Penerus. Jakarta: Info POM.

[5] Core, 2003. Positive Deviance \& Health (Suatu Pendekatan Perubahan perilaku \& Pos Gizi). Jakarta.

[6] Dilliani, 2011.Pengaruh Pendidikan Kesehatan dengan Metode Role Play Terhadap Perilaku Personal Hygene pada Anak Kelas III di SD Pandak I Bantul. Skripsi. STIKes Aisyiyah.

[7] Fitri C.N., 2012. Faktor-Faktor yang Berhubungan dengan Kebiasaan Konsumsi Makanan Jajanan pada Siswa Sekolah Dasar di SDN Rawamangun 01 Pagi Jakarta Timur Tahun 2012. Skripsi. FKM UI.

[8] Haryanto, T., 2014. Penggunaan Metode Bermain Peran untuk Meningkatkan hasil Belajar PKN Siswa Kelas V pada MI Maarif Mantingan Salam Magelang Tahun Ajaran 2013/2014. Skripsi. UIN Sunan Kalijaga.

[9] Hermina, Afriansyah, N., 2010. Jurnal Penelitian Gizi Makanan. Pengembangan Permainan (Game-Play) Edukasi Gizi Berbasiskomputer untuk Murid Sekolah Dasar. PGM Vol. 33 No.2: 161-172.

[10] Hidayati, Jati D.I.K., 2011. Jurnal Mutiara Medika. Pengaruh Pelatihan Gizi dengan Metode Roleplay dan Audiovisual Terhadap Tingkat Pengetahuan dan Sikap Tentang Gizi di Wilayah Kerja Puskesmas Kasihan I Bantul. JMM Vol. 11 No. 3: 139-145.

[11] Ikada, D.C., 2010. Tingkat Penerimaan Buku Cerita Bergambar Sebagai Media Pendidikan Gizi dan Pengaruhnya Terhadap Pengetahuan Gizi Anak Sekolah Dasar. Skripsi. Fakultas Ekologi Manusia Institut Pertanian Bogor.

[12] Kemenkes RI.. 2015. Situasi Pangan Jajan Anak Sekolah. Jakarta : Info Datin Kemenkes RI. 
[13] Kisnawaty P.,2013. Keefektifan Metode Role Playing Terhadap Hasil Belajar Pendidikan Kewarganegaraan Materi Keputusan Bersama Siswa Kelas V Sekolah Dasar Negeri 3 Randugunting Kota Tegal. Skripsi. Universitas Negeri Semarang

[14] Kristanto Y, 2013. Faktor Determinan Pemilihan Makanan Jajanan pada Siswa Sekolah Dasar. Skripsi. Jurusan Gizi Politeknik Kesehatan Kementerian Kesehatan Malang.

[15] Notoatmodjo, S., 2007. Promosi Kesehatan dan Ilmu Perilaku. Jakarta : Rineka Cipta

[16] Peni, R., 2009. Pengaruh Penerapan Sosiodrama (Bermain Peran) Terhadap Minat dan Prestasi Belajar Kimia Siswa MAN X Klaten Smester Gasal Tahun Ajaran 2008/2009. Skripsi. UIN Sunan Kalijaga.

[17] Sartika, R.A.D., 2012. Jurnal Kesehatan Masyarakat. Penerapan Komunikasi, Informasi, dan Edukasi Gizi Terhadap Perilaku Sarapan Siswa Sekolah Dasar.

[18] Sudarmin, R.R., 2014. Analisis Program Gerakan 21 Hari (G21H) Cuci Tangan Pakai Sabun Terhadap Kejadian Diare Pada Siswa(I) Sekolah Dasar Di Kota Makassar. Tesis. FKM Unhas.

[19] Suswanti. 2013. Faktor-Faktor yang Berhubungan dengan Pemilihan Makanan Cepat Saji pada Mahasiswa Fakultas Kedokteran dan Ilmu Kesehatan UIN Syarif Hidayatullah Jakarta Tahun 2012. Skripsi. UIN Syarif Hidayatullah.

[20] Zumaroh, 2012.Penggunaan Metode Role Playing untuk Meningkatkan Prestasi Belajar PAI Siswa Kelas V SD Negeri Donorojo Mertoyudan Magelang Tahun 2012. Skripsi. PAI STAIN Salatiga. 